\title{
Development and Democratisation in East and Southeast Asia
}

\author{
Jamie Mackie
}

$\mathrm{A}$

broadly positive correlation can be observed throughout the world (although there are several significant exceptions) between various countries' levels of economic development and their degree of progress towards democratic institutions (Lipset, 1959, 1960; Huntington, 1991). But in Southeast Asia the exceptions are so striking as to disallow us from simply assuming that the one causes the other. ${ }^{1}$ The connections are much more complex than that, and the theoretical assumptions involved as well as the empirical data demanding explanation turn out to be tangled up with other factors as well.

'The more well-to-do a nation, the greater the chances it will sustain democracy', wrote Lipset (1960:48-50) about the more advanced industrial countries in the early years of debate on this topic. Much the same has been said about the developing countries since the 1970 s, most notably the fast-growing nations of Southeast and East Asia, in contrast with the poorer countries of Africa and elsewhere, most of which (apart from India) are not very democratic at all (Morley, 1993/1998; Friedman, 1994; Linz \& Stepan, 1996). But correlation does not in itself signify causation.

The central issue is why steps towards more democratic government (as defined below) have occurred in some countries in Fast and Southeast Asia over the last 40 years as they have become wealthier and generated a larger, more influential middle class, whereas in others no such political change has resulted from rapid growth, despite the emergence of large middle classes. The broader theoretical issues that have arisen in the now extensive literature on this subject can only be touched on briefly here. Essentially, this article seeks to answer several questions that are often asked in this context. Is rapid growth conducive towards democratisation in all circumstances, or do other factors also come into play? Or does the converse apply: that is, that authoritarian governments or strong states, capable of curbing civil and political liberties, are essential to get the growth process started? Or is there an element of truth in both these propositions (as I will argue, with qualifications on both counts), and if so, how are the two to be related or distinguished? The impact and extent of the 1997-98 financial crisis will have to be left out of consideration, as

${ }^{1}$ The connection may be closer in Northeast Asia, apart from China and North Korea.

Jamie Mackie is Professor Emeritus in the Research School of Pacific and Asian Studies at The Australian National University. 
will unwarranted occasional assertions that the growth achieved in the years before then was not real or rapid, even though flaws were already visible behind the supposed 'economic miracle' in all countries of the region, including Japan. As well, China and the other highly authoritarian communist states of the region will be left out of account here, as will the two maverick cases of Myanmar (Burma) and Brunei.

\section{No Simple Link}

Taiwan and South Korea were certainly authoritarian regimes in the earlier phases of their post-independence economic development. A causal connection seems to have been at work, since the two strong state systems were able to get rapid growth started well before most other countries, for reasons outlined below. After experiencing rapid economic growth for over 20 years, each country developed a large middle class which played a major part in the struggles in the 1980 s to achieve more democratic institutions, which now seem to be securely established. Thailand was also an authoritarian regime at the time when its rapid growth phase started in the 1950-60s, although it was never such a 'strong' state as Taiwan and South Korea. It too began to change gradually towards a more democratic form of government from the mid-1970s onwards, especially during its 1986-96 boom years. The gradual consolidation of its political parties and parliamentary system, though badly flawed by 'money politics', was sufficient to defeat a military coup d'état in 1992 and to establish party-based parliamentary governments since then.

Japan, on the other hand, has, throughout its five decades of astonishingly rapid growth, had a formally democratic set of political institutions, which were imposed under the postwar US occupation. Yet its system of government could not be said to have become significantly more responsive to social demands and pressures during that lime, or more democratic or participatory, or capable of curbing the immense power of the bureaucracy. Likewise, Malaysia and Singapore have long had the formal trappings of democracy which they inherited as British colonies about 40 years ago; but the actual practice of representative government there has not become in any sense more democratic as they have grown wealthier: if anything, the reverse. Singapore is in practice a highly authoritarian one-party regime, and Malaysia semi-democratic, or 'responsive-authoritarian' (Crouch, 1996) at best, despite their high growth rates, the highest per capita income levels in Southeast Asia, and large middle classes. The Philippines also inherited a set of democratic institutions, on a US-style congressional model, with parties and regular elections; yet it has experienced fluctuations towards a dictatorship under Ferdinand Marcos (1972-86) and back towards a rather chaotic, ineffectual democratic regime since then, thus defying any clear-cut generalisation about the links between growth and democracy.

Indonesia has been the most striking exception to any such proposition, for its rapid economic growth during 1966-97 gave rise to an immense increase in the power of the state, largely concentrated in the hands of President Suharto himself, within a highly personal and patrimonialist system of government and at the ex- 
pense of the civil society. Hence, growth has been accompanied there by a weakening of representative institutions (the word democracy is hardly relevant in the Indonesian context) rather than the reverse.

From this bald survey, it is clear that no simple link is discernible between economic development and democratisation in the fast-growth countries of eastern Asia. While there is some evidence in favour of such a proposition in the cases of Taiwan, South Korea and Thailand, the opposite is the case for Indonesia, Singapore and Malaysia. Other variables have to be taken into account in each case.

\section{'Democracy' and 'Democratisation'}

Something more must be said at this point about the meaning attributed here to terms like 'democracy' and 'democratisation'. (The latter is less problematic since it simply means a process of change broadly in the direction of democracy.) Both terms are used here loosely and generally, descriptively rather than normatively, to indicate how nearly any particular regime approximates to an ideally democratic system of government in which the executive power is responsive to the views, preferences and demands of the people, as expressed through institutions such as elections, political parties, a parliament or congress and a set of rules to ensure that the executive is periodically accountable to the parliament or the people. The cases of Singapore, Malaysia and Japan, as mentioned above, which all appeal to values other than those of conventional Western 'liberal democracy', indicate clearly that it is not just the presence or absence of those institutions that matters most but the ways in which formally democratic institutions actually work. Equally important are the more deeply rooted social attitudes and values which imbue them, particularly on issues such as freedom of expression and the press, the autonomy of the courts, the beliefs of both governments and citizens about human rights, legal and civil rights and obligations, and ideas about the individual and the community, society and state, all of which vary widely throughout the developing world.

The term 'illiberal democracies' has been coined by Fareed Zakaria (1997) to refer to regimes (mainly in the Balkans, Africa and Central Asia, but applicable also to some Southeast Asian countries) that hold free elections but do not respect the rights of their citizens. Zakaria (1997) urges a greater emphasis on reviving constitutionalism and the rule of law rather than the 'fixation on ballot boxes' (Kupchan, 1998:122). Yet according to Kupchan, 'the current wave of democratisation is taking place in regions which have little or no experience in constitutional liberalism' but rather 'a long history of paternalism and social norms that privilege the group over the individual'. Kupchan disagrees with Zakaria's advocacy of promoting constitutionalism before democracy, arguing that liberalism has preceded democracy only in the Anglo-Saxon West where 'political culture, practices and institutions were already imbued with the spirit of constitutional liberalism' long before democracy took root there. He urges that even an imperfect democracy can serve 'as a beachhead for liberal values, not vice versa' and that 'illiberal democracy may be a way station along the road to more benign forms of government ... from autocracy towards liberalising autocracy, and in some cases towards liberalising semi- 
democracy' (1998:123). This aspect of the subject, though a most important one, cannot be adequately explored here, for the related question of 'Asian values' in all this is a complex and subtle one. But it should be kept in mind as we explore the factors involved in whatever explanatory model may be advanced about economic growth and progress towards democratisation.

\section{Is Authoritarianism a Necessary Condition of Growth?}

The proposition that strong government and curbs on civil and political liberties were essential for initiating growth rested on the belief that only an authoritarian regime could impose unpopular but necessary policies involving industrial discipline, resistance to high wage levels, suppression of militant trade unions and peasant organisations: in short, insulation from the demands of special interest groups. High levels of governmental autonomy seemed to be necessary in the early stages of growth and 'primitive accumulation of capital' in order to avoid the weaknesses of what Gunnar Myrdal (1968) called 'soft states' without an effective capacity to carry out the policies they ordained. South Korea and Taiwan were the examples most commonly cited in favour of this view in the 1960-70s, with Singapore under Iee Kuan Yew and Indonesia under Suharto later being added to the list, as well as the Philippines under the Marcos dictatorship of 1972-86 (but the Philippines had the highest income levels in Southeast Asia and high rates of growth during the 25 years of democratic government before 1972).

Dependency theorists were inclined to use this sort of argument to support their belief that the ruling elites of those countries were being covertly manipulated by huge foreign multinational corporations which were thought to be acting in collusion with the elites to advance the interests of both parties at the expense of the rest of the population (the workers and peasants in particular) so as to enmesh the economies of those countries into the global capitalist system. There was a grain of truth in that argument, although the cruder claims about the dominance of foreign capital and subservience of the state to it were later seen to be misleading. Singapore, for example, has relied heavily on foreign capital, yet the Peoples Action Party government has proved to be highly autonomous, insulated from society-based pressure groups, patently not the servant of either multinational corporations or domestic capitalists but their master. In the early stages of development of Taiwan and South Korea, foreign direct investment played a relatively small part (although foreign aid from the US and overseas loans were crucial) and the governments of those countries were highly autonomous.

More sophisticated variants on the growth-authoritarianism theme emerged in the 1980s with Chalmers Johnson's (1987) influential 'developmental state' theory, based on his interpretation of the structural basis of rapid growth in Japan and the newly industrialising countries (NICs) South Korea, Taiwan, Singapore and Hong Kong (a very disparate array of politico-economic systems), and an interpretation in terms of 'growth coalitions' as the political basis of fast growth in those countries by Stephan Haggard and Cheng Tun-jen (1987). 
Johnson's idea of the 'developmental state' was not concerned directly either with the authoritarianism-democratisation debate (for the prospects of democratisation would have seemed bleak in Taiwan and South Korea when he first used the term in 1981) regarding necessary and sufficient conditions for development, or with the growth-democratisation nexus, so much as with the question of how the political elites in those countries had avoided capture by their major clients, especially privately owned big business. But he did stress the 'strong state' feature of these countries in the course of showing the importance of government intervention in economic life in Japan, South Korea and Taiwan, contrary to the views of laissezfaire economists who stressed only on their reliance on market forces and exportoriented economic policies. But the model he advanced also focused on four main elements behind the economic success of the Asian NICs:

stable rule by a political-bureaucratic elite not acceding to political demands which would have undermined economic growth; cooperation between public and private sectors under the overall guidance of a pilot planning agency; heavy and continuing investment in education for everyone, combined with policies to ensure equitable distribution of the wealth created by high-speed growth; and a government that understands the need to use and respect the methods of economic intervention based on the price mechanism. (Johnson, 1987:145)

Haggard and Cheng (1987) put forward a less muscle-bound variant of the developmental state theory in their study of Taiwan, South Korea, Hong Kong and Singapore, the then generally accepted group of Asian NICs. They too stressed the 'insulated' character of the state in all four NICs, but put more emphasis than Johnson did on the part played also by repression of workers and labour organisations. Their main contribution was to show how various 'growth coalitions' within elite and business circles had come to reject import-substituting industry policies and to support export-oriented growth based on market-conforming modes of government intervention in economic life. They drew on dependency theory in their stress on the triangular relationship between the domestic bourgeoisie, foreign capital and the state as the key players determining the formulation of export-led growth strategies. But they were not the prisoners either of old Marxist assumptions that the economic success of these countries was due mainly to the exploitation of the workers through low wage levels, or of the dependency-theory belief that the governments and business elites of these countries were hand-in-glove with foreign capitalists to whom they were beholden. The value of their approach to the analysis of the sociopolitical dynamics of economic policy-making in the NICs lay in providing an account of the relatively autonomous 'strong' state which led towards a more flexible and nuanced view of the relationship between state and society in these countries. This approach was not invalidated when Taiwan and South Korea suddenly and surprisingly shifted towards more democratic regimes in 1985-87, for the study of the state-society balance and business-government relations in the processes of eco- 
nomic policy-making which flowed out of their work has become much more diverse, flexible and illuminating not only for those two countries but also for others in the region.

Yet applying either the 'developmental state' or the 'growth coalitions' approach to Southeast Asia creates difficulties, quite apart from the special problems posed by Singapore as a Southeast Asian NIC (Mackie, 1988). For example, Thailand, formerly considered the archetypal 'bureaucratic polity' which was highly insulated from social pressures, could not be accurately described in terms of Johnson's developmental state theory even in the years of intensely authoritarian rule by military juntas before 1973. Subsequently, its phases of most rapid economic growth have occurred since the 'democratic interlude' of 1973-76 and the decline in state autonomy. That was followed, after a brief phase of return to military rule, by gradual steps towards democratisation and rejection of military intervention in government during the 1980s under General Prem Tinsulanond, especially during the boom years 1986-96. The government and its policies were never dominated by US or Japanese private capital, even though foreign direct investment rose steadily during that period and then very rapidly after 1986 (Pasuk \& Baker, 1996). Likewise, Malaysia has never had an especially 'strong', authoritarian or 'insulated' state since independence, although it has at best been only a semi-democratic one; yet it has had steadily high growth rates ever since the late 1950s (Crouch, 1996). Wages have not been kept low there, as in the developmental state model, and the influence of British capital has declined steadily since the 1970s. The Philippines and Indonesia have had even more complex patterns of economic and political development since 1945, which can be explained only in terms of their particular circumstances, in defiance of dependency theory or developmental state models rather than in accordance with them (Mackic, 1993/1998).

Thus we are left with two unresolved problems here - and perhaps others that flow from them. First, if it is not the case that highly authoritarian regimes have been more easily able to get growth started than relatively democratic ones (however we may define these terms; it is better to think of them loosely as opposite poles of a spectrum rather than as sharply dichotomous), what are the political underpinnings of economic growth? This is not the place to go into that question at any length, since it is the obverse of our primary concern here, which is with the political consequences of growth, not its causes or preconditions. I have tried to investigate the latter elsewhere (Mackie, 1988) with reference to the (then) ASEAN states, but it is sufficient simply to note one very general observation here.

Authoritarian states have obviously not been successful in generating growth in many countries in Africa, the Middle East and elsewhere, while several in the AsiaPacific region have successfully achieved high growth rates without having highly authoritarian regimes (Thailand most obviously, Malaysia and the Philippines less so). But while authoritarian government may not be a sufficient condition for rapid growth to occur, it may arguably be a necessary condition for getting the growth process started, by enabling governments to hold down wage levels, generate high savings and investment levels, and direct scarce capital towards infrastructure and 
human capital rather than consumption. It is hard to identify any countries which have achieved high growth rates without relatively authoritarian regimes, apart from the rather special case of the Philippines in the 1950-60s, where the role of US capital, aid and policy advice was substantial.

But perhaps it was not authoritarianism as such that was critical to the initial growth process so much as 'insulated' or autonomous governments and a high degree of bureaucratic competence. Equally important may have been the ability of governments in Taiwan, South Korea and Singapore to avoid 'capture' by either rent-seeking business firms or radical unions, and so to enforce the rules of the game that kept markets competitive and a level playing field). Those conditions did not apply in the Philippines under Marcos, or in Indonesia under Suharto, although markets were liberalised to some extent and growth generated at lower levels. Malaysia benefited from a very competent bureaucratic structure, a relatively open trade regime, and not too much 'capture' by special interest groups in the early stages of development.

Second, what can be said about the links, if any, between economic growth and pressures for democratic reform, whether successful or not, from various elements within the society? I want to approach this question by, first, examining the importance of the middle class as a key element in the socio-political chemistry involved; second, by touching briefly on Samuel Huntington's analysis of the post-1970 'Third Wave' of transitions from authoritarian to democratic regimes throughout the world; and finally by turning to the problems of applying this kind of explanation to the five original ASFAN countries.

\section{Growth, the Middle Class and Democratisation}

It is commonly asserted that democratising tendencies in developing countries are due wholly or largely to the growth of a middle class, educated, urbanised and bound up with the modern world, upholding the prevailing ideas and (in part) ideologies of their counterparts in more advanced industrialised societies. Members of the middle class have a stronger interest than most other social groups in pressing authoritarian regimes to widen and strengthen the civil liberties of their citizens, to minimise the arbitrary authority of officialdom or the military, and to move towards a rule-based administration and the rule of law. Even if they do not go so far as to press strongly for fully 'democratic' forms of government (for they may find themselves outvoted by the workers or peasants in a genuinely democratic electoral system, or severely repressed by military or right-wing elements in authoritarian regimes if they push too far), they are likely to be broadly in favour of reforms in the direction of a more accountable executive power that is responsive to pressures from social groups, if only to cope with the greater complexity of policy-making in an increasingly industrialised society. But while the strength of middle class elements in developing countries may be correlated to some extent with the levels of industrialisation, urbanisation and education prevailing in a particular country, we cannot assume there is an automatic or inevitable process at work here which leads towards a strengthening of democratisation tendencies. The Philippines, for in- 
stance, had by far the largest and best educated middle class in Southeast Asia in the 1960 s at the very time when Marcos plunged the country into martial law and a highly regressive dictatorship, with surprisingly little effective resistance from the middle class (and even much support).

The various studies of 'transitions from authoritarianism' by O'Donnell, Schmitter and Whitehead (1986), mostly in southern Europe or South America, were of value in pointing beyond simplistic generalisations about the growth of a middle class as a factor in democratisation towards the interactions and negotiating processes that take place within authoritarian regimes between various political actors both inside and outside the state structure who are involved in struggles to alter or retain the status quo. They were particularly good in their analysis of the complex politics of negotiation there between the duros and blancos (hard-liners and soft-liners) as to the choice of repressive or accommodating policies towards opponents of the state. In nearly all cases where transitions from authoritarian rule have occurred, the rifts between duros and blancos have at times provided enough scope for the advocates of change to be able to drive wedges between them and make limited gains in the direction of more democratic political institutions.

Just as the widespread failures of democratic systems in developing countries in the years after 1958 and the emergence of authoritarian regimes there attracted a lot of attention among Western political scientists at that time, the pendulum has swung in the opposite direction since the 1970s. Huntington's (1991) 'Third Wave' study of the circumstances surrounding the numerous shifts towards democratic governments throughout the world since about 1970 provides one of the most comprehensive studies of the various factors which help to account for this trend across the world, of which economic growth and the emergence of an educated middle class are merely two, and not necessarily the most decisive ones. Like the 'transitions' analysts, Huntington highlights the roles played by political actors on both sides, as well as the prevailing economic circumstances within which they had to act. On the relevance of levels of economic development to the probability of achieving democratic reforms, he observes that:

Very rapid economic growth inevitably produced challenges for authoritarian leaders. It did not necessarily lead them to introduce democracy ... Over the long term, economic development creates the basis for democratic regimes. In the short term, very rapid economic growth and economic crises may undermine authoritarian regimes. If economic growth occurs without economic crisis democracy evolves slowly, as it did in nineteenth century Europe. If the destabilising growth or economic crisis occurs without the achievement of transition zone wealth, authoritarian regimes may fall, but their replacement with long-lived democratic regimes is highly problematic. In the third wave, the combination of substantial levels of economic development and short-term economic crisis or failure was the economic formula most favourable to the transition from authoritarian to democratic government. (Huntington, 1991:72) 
While not very elegantly expressed, this extract does underline the important point that any search for correlations between growth and democratisation needs to look well beyond any simple one-to-one relationship towards, for example, the role of crises in destabilising authoritarian regimes (and thereby opening up opportunities for the advocates of democratisation) and the conditions determining the sustainability of democratic governments once they are established.

\section{The Growth-Democratisation Nexus in Southeast Asia}

In the most thorough and sustained enquiry yet made into the correlation between economic development and democratisation tendencies in the major countries of East and Southeast Asia, Crouch and Morley (1998) have shown that while Lipset's observation quoted earlier (that the wealthier a nation 'the greater the chances that it will sustain democracy') is broadly true of this region, there are some notable exceptions. Three of the four countries with the highest per capita income levels in the region in the 1990s - Japan, Taiwan and South Korea - are classified as 'consolidated democracies', while the fourth, Singapore, is categorised as 'authoritarian-responsive', even though its income levels are nearly twice those of Taiwan and three times South Korea's. At the other end of the scale, China, Vietnam and Myanmar, all still in the low-income category, have authoritarian regimes of various types. Of the middle-income countries, Malaysia, Thailand and the Philippines are classed as formally democratic, despite various imperfections, but Indonesia, the poorest of them, is regarded as 'authoritarian-military', despite its high growth rates over the last 30 years and despite the fact that it had earlier had more than a decade of vigorously democratic, party-based parliamentary government in the years $1945-59$, at a time of much lower per capita income levels than in the 1990 s.

One of the conclusions that Crouch and Morley (1998) draw is that:

It is not accidental that medium levels of economic growth are commonly associated with instability, most political regimes weaving between authoritarian structures and [merely] formal democracies, while the higher levels are generally correlated with democracy ... These correlations would appear to be in large part the effects of the growth process itself, mediated through the social and political processes it generates ...

Beyond this point, the analytical problem becomes partly a matter of explaining the anomalous cases of Singapore and Indonesia (and to a lesser extent Malaysia and the Philippines), while also depicting a more refined and flexible explanatory model for the observable patterns of socio-political change. Using what is essentially Karl Deutsch's notion of social mobilisation as a key element in the equation, Crouch and Morley (1998) have put forward a stylised explanation in terms of what they call the 'driven-by-growth model', subject to the assumption that all other factors are equal, which is a very important qualification (since they rarely are equal in this part of the world), as follows: 
Economic development drives social mobilisation;

Social mobilisation drives political mobilisation;

Political mobilisation drives regime change.

Not all regime changes will result in democratisation, however, at least as it is understood in the West, and it would be erroneous to treat this 'model' in too deterministic a manner by implying that democratisation is an inevitable outcome of either economic development as such or the social or political mobilisation it generates. Other variables must also be brought into account, particularly ideologies, 'Asian values' and institutional factors such as the role of the armed forces, the strength or weakness of political parties, freedom of the press, the competence of bureaucracies, the autonomy of the judiciary and older traditions about individual freedom vis-à-vis the community.

Authoritarian regimes can be expected to respond to the pressures generated by social and political mobilisation in different ways, some moving towards more representative or democratic directions, other creating new institutions which will enable them to accommodate pressures from below without making concessions towards demands for democracy. Obvious examples of this are Singapore's resort to a quasi-one-party regime since 1965 and Indonesia's shift to a highly authoritarian 'Panca Sila democracy' based on the state-controlled Golkar organisation, the armed forces' civic-mission type 'dual function' and a highly conformist, patrimonialist political system. Moreover, specific local factors may also come into play in varying degrees, such as the ethnic cleavage in Malaysia, where the Malays have long feared they might become subordinated in their own land by the wealthy Chinese minority, or the acute sense of vulnerability felt by the Chinese in tiny Singapore. Hence:

The four anomalous cases do not ... contradict the argument that high economic development strengthens the forces leading towards democratisation. What they do show is that the impact of economic development must be weighed in the context of other forces, which may strengthen or weaken it ... Our analysis [is put forward] ... not as a formula for precise prediction, but as an instrument for sensitising one to some of the more potent forces with which we shall all have to grapple. (Crouch \& Morley, 1998)

Among the 'other forces' which enter the equation as intermediate variables, according to Crouch and Morley, are geographical factors (varying from Singapore's extreme smallness and sense of vulnerability to China's immense size and Indonesia's potentially fissiparous character), political culture, deeply entrenched political institutions, elite cohesiveness, social factors such as communal divisions and social stratification, and vulnerability to external pressures. The influence of dominating personalities (I ee Kuan Yew, Suharto, Sukarno, Marcos and Mao Tse-tung most obviously, but several others too) has often been significant in directing their na- 
tion's course towards either authoritarianism or democracy. Hence any enquiry into the strength of democratising forces in these countries must look beyond mere economic indicators like growth rates or per capita income levels, as if these were the key determinants, to take account of the intricacies of their history and politics also.

It is here that the various other issues raised in the studies by O'Donnell et al. (1986) of 'transitions from authoritarianism' also become relevant to any investigation into the issues under scrutiny here. They have not had much attention in the Southeast Asian context, however, not least because the only clear-cut examples of such transitions so far have been the overthrow of Marcos in the Philippines in 1986 (Mackie, 1993, 1998), of the military junta in Thailand in 1992, and of Suharto in 1998. A more fruitful approach to these matters in the various Southeast Asian countries may be along the lines of Haggard and Kaufmann's (1995) analysis of the relevance of institutional factors to regime change or survival, either authoritarian or democratic:

The ability of both authoritarian and democratic leaders to maintain power is a function of economic performance, which in turn is dependent on the conduct of cconomic policy. Institutions affect the coherence of policy both in the initiation phase, when executive authority is an asset, and during the consolidation phase when success rests on building bases of social support. (Haggard \& Kaufmann, 1995:10)

This approach directs our attention to the sustainability of democratic institutions and processes after any transition from authoritarianism has occurred, which is likely to be a matter of crucial importance in the long run. Democratisation cannot be regarded as just a linear, one-way process, in any part of the world.

There are strong grounds for doubting that transitions from authoritarian into democratic regimes will prove sustainable unless they have established 'the social supports that usually only advanced economies can supply' (Crouch \& Morley, 1998). The decisions of political actors may be crucial for determining the immediate direction and timing of regime changes, but they are made in a social context in which the level of economic development remains a fundamental element and one that is likely to have a serious impact on the sustainability of any changes made' (Crouch \& Morley, 1998). In short, poor and crisis-prone countries are likely to have trouble maintaining democratic regimes, even if they are fortunate enough to achieve them, whereas more prosperous countries have better chances of doing so - provided they too have been fortunate enough to achieve them, which is not always the case. 


\section{References}

Crouch, H. (1996), Malaysia: Government and Society, Cornell University Press, Ithaca.

_ \& J. Morley (1998, forthcoming), 'The Dynamics of Political Change', in J. Morley (ed.), Driven by Growth: Political Change in the Asia-Pacific Region, Sharpe, Armonk, N.Y.

Friedman, E. (ed.) (1994), The Politics of Democratization: Generalizing East Asian Experiences, Westview Press, Boulder.

Haggard, S. \& C. Tung-jen (1987), 'State and Foreign Capital in the East Asian NICs', pp. 84-135 in F. Deyo (ed.), The Political Economy of the New East Asian Industrialism, Cornell University Press, Ithaca.

Haggard, S. \& R. Kaufmann (1995), The Political Economy of Democratic Transitions, Princeton University Press, Princeton.

Hunington, S. (1991), The Third Wave: Democratization in the Late Twentieth Century, University of Oklahoma Press, Norman.

Johnson, C. (1987), 'Political Institutions and Economic Performance', pp. 136-64 in F. Deyo (ed.), The Political Economy of the New East Asian Industrialism, Cornell University Press, Ithaca.

Kupchan, C. (1998), 'Democracy First', Foreign Affairs, May-June: 122-5.

Linz, J. \& A. Stepan (eds) (1996), Problems of Democratic Transition and Consolidation: Southern Europe, South America and Post-Communist Europe, Johns Hopkins Press, Baltimore.

Lipset, S. (1959), 'Some Social Prerequisites for Democracy: Economic Development and Political Legitimacy', American Political Science Review 53: 69-105.

— (1960), Political Man, Heinemann, London.

Mackie, J. (1988), 'Economic Growth in the ASEAN Region: The Political Underpinnings', pp. 283 326 in H. Hughes (ed.), Achieving Industrialization in East Asia, Cambridge University Press, Cambridge.

- (1993/1998), 'Indonesia: Economic Growth and Depoliticization' and 'The Philippines: an Unusual Case' (with Bernardo Villegas), pp. 69-118 in J. Morley (ed.), Driven by Growth: Political Change in the Asia-Pacific Region, Sharpe, Armonk, N.Y.

_ \& A. Macintyre (1994), 'Politics', pp. 1-53 in H. Hill (ed.), Indonesia's New Order. The Dynamics of Socio-Economic Transformation, Allen \& Unwin, Sydney.

Morley, J. (ed.) (1993/1998), Driven by Growth: Political Change in the Asia-Pacific Region, Sharpe, Armonk, N.Y.

Myrdal, G. (1968), Asian Drama: An Enquiry into the Poverty of Nations, Penguin, London.

O'Donnell, G., P. Schmitter \& L. Whitehead (eds) (1986), Transitions from Authoritarian Rule: Comparative Perspectives, Johns Hopkins University Press, Baltimore.

Pasuk Phongphaichit \& C. Baker (1996), Thailand's Boom, Silkworm Press, Chiangmai.

Zakaria, F. (1997), 'The Rise of Illiberal Democracy', Foreign Aftairs, November-December: 22-43. 